\title{
Should Organic Agriculture Maintain Its Opposition to GM? New Techniques Writing the Same Old Story
}

\author{
Fern Wickson ${ }^{1, *,+}$, Rosa Binimelis ${ }^{1,2,+}$ and Amaranta Herrero ${ }^{1,+}$ \\ 1 GenØk Centre for Biosafety, Siva Innovasjonssenter, PB 6418, Tromsø 9294, Norway; \\ rosa.binimelis@uvic.cat (R.B.); amaranta.herrero@genok.no (A.H.) \\ 2 Agroecology and Food Systems Chair, University of Vic-Central University of Catalonia, c/de la Laura, 13, \\ Vic 08500, Spain \\ * Correspondence: fern.wickson@genok.no; Tel.: +47-776-231-37 \\ + These authors contributed equally to this work.
}

Academic Editor: Gerhart U. Ryffel

Received: 8 July 2016; Accepted: 26 October 2016; Published: 28 October 2016

\begin{abstract}
Biotechnology is diversifying rapidly through the development and application of new approaches to genome editing and ongoing research into synthetic biology. Proponents of biotechnology are enthusiastic about these new developments and have recently begun calling for environmental movements to abandon their campaigns against Genetically Modified Organisms (GMOs) and for organic agriculture to reconsider its exclusion of Genetic Modification (GM). In this article, we begin by describing the diversity of practices that cluster under both the terms GM and organic and show that although there is a clash of different cultures of agriculture at stake, there is also a spectrum of practices existing between these two poles. Having established the terms of the debate, we then go on to analyse whether the organic movement should reconsider its position on GM in light of new plant breeding techniques (NPBTs), using the criteria highlighted as important by the International Federation of Organic Agriculture Movements (IFOAM) in their $2016 \mathrm{draft}$ revised position on GMOs. Through this analysis, we suggest that given the in-context-trajectory of biotechnology development, the continued narrow framing of agricultural problems and the ongoing exclusion of important socio-economic, political and cultural dimensions, the organic movement is justified in maintaining its opposition to GM in the face of NPBTs.
\end{abstract}

Keywords: GM; GMO; agricultural biotechnology; organic; agroecology; sustainability; agri-food systems; new plant breeding techniques (NPBTs)

History, culture and community values are embedded in agriculture [1]

\section{Introduction}

According to the International Federation of Organic Agriculture Movements (IFOAM), the intentional use of Genetic Modification (GM) is, in principle, excluded from organic systems [2]. While recognising the need to handle the potential presence of GM materials in organic products by unintentional contamination, and permitting the unique exception of GM vaccines in organic livestock production when welfare concerns are significant and no other alternatives are available, IFOAM affirms that Genetically Modified Organisms (GMOs) and their derivatives currently have no place within organic systems [3]. This continues the line of thinking established by the very early pioneers of the organic movement, like Albert Howard, in which all artificial forms of breeding and insemination were not supported as necessary or desirable [4]. Despite a lack of interest, need or demand by the organic movement for GM technologies, this special issue questions this exclusion and asks whether there might be a role for GM within the organic movement, especially in light of the emergence of new plant breeding techniques, commonly referred as NPBTs or NBT. This question 
arguably becomes especially pertinent when we consider a future beyond the existing technologies of transgenic herbicide-tolerant and pesticide-producing plants, which clearly fail to advance an organic agenda, to one in which there is the potential to employ a range of new techniques to work within species genomes to satisfy a shared commitment to sustainability [5].

IFOAM Europe recently released a public position statement calling for these NPBTs to be recognised as GM and regulated as such [6]. Since the European organic regulation does not allow the use of GMOs [7], the organisation therefore deems these new techniques and any organisms generated through their use as incompatible with the principles of organic agriculture. The aim of this paper is to explore the opposition that the organic movement has shown to GM, extract and articulate its basis, and then assess it in light of NPBTs. By examining the 2016 draft IFOAM Position Statement on Genetic Engineering and Genetically Modified Organisms [3] (revising the 2002 position [2] and still open for public consultation at the time of writing) and the published position of IFOAM Europe on New Plant Breeding Techniques from 2015 [6], we will demonstrate how given the conditions that need to be met for GM to align with organic standards and ideals, the movement's aversion towards GM still holds in the face of NPBTs.

The article is divided into four sections. In the first two sections, we describe the diverse sets of meanings and practices that cluster around the concepts of organic and GM, respectively. In these sections we seek to clarify what is meant by the terms organic and GM, show the diverse interpretations that can be applied to these terms, and highlight how we will be using them in this paper. In the section that follows, we then articulate the argument that there is a clash of cultures of agriculture (agri/cultures) involved when GM and organic proponents advocate their positions (including a divergence in scientific paradigms, philosophical worldviews, social values, and political orientations). At the same time, we suggest that there is a field of grey in between the extreme poles on either side of this clash. Finally, we use the remaining sections of the paper to analyse how IFOAM articulates its opposition to GM and consider how they relate to NPBTs and whether NPBTs are likely to be given a place in the organic farming of the future.

\section{Results}

\subsection{Defining What Is Organic}

As a term, organic agriculture encompasses a diversity of actors and agricultural practices that extend beyond those involved in certified organic production. According to a consensus definition articulated on the website of the umbrella organisation International Federation of Organic Agriculture Movements (IFOAM) [8], organic agriculture is:

"[ ... ] a production system that sustains the health of soils, ecosystems and people. It relies on ecological processes, biodiversity and cycles adapted to local conditions, rather than the use of inputs with adverse effects. Organic agriculture combines tradition, innovation and science to benefit the shared environment and promote fair relationships and a good quality of life for all involved."

As indicated by this definition, organic agriculture combines modern scientific knowledge with traditional farming practices. It aims to advance a sustainable production system adapted to local conditions based on promoting and utilising biodiversity and enhancing soil fertility. It does this, for example through crop rotation and nutrient recycling using farm-derived, renewable and local resources rather than relying on external inputs such as synthetic pesticides and fertilisers, hormones and antibiotics.

The concept of organic farming practices started being articulated in the early 1900s in response to a degradation of soils and loss of fertility $[9,10]$ but did not really become popularised until the 1970s [11-13]. At this time, the term began to be used to specifically refer to a range of agronomic and marketing practices that developed in opposition to the spread of an industrial model of agriculture based on an intensive use of external chemical inputs; a model that was amplified 
during the Green Revolution and viewed as having extensive unacceptable social and environmental consequences [14]. The vision of organic agriculture was soon (perhaps poorly) translated into normative certification criteria that merely prohibited certain synthetic inputs. This allowed for global standardisation but reduced the visions and values of the organic model, losing part of its initial diversity [15]. This impoverished understanding or interpretation has led to the development of a "conventionalization" of organic agriculture [16], in which many certified organic farming operations have simply substituted the unacceptable synthetic inputs for permitted organic ones yet still operate within large-scale global market-oriented systems under an agri-business model.

In recent years though, there has been a significant push to try and reconceptualise and reestablish the meaning of organic agriculture in a broader sense than simply agricultural production without external chemical inputs. This includes a better integration of the initial holistic vision with social and political values. The (re)integration of non-agronomic aspects into the definition and understanding of organic agriculture has been deemed extremely important to respond to the trends towards industrialisation, commodification, corporatisation and specialisation. These trends characterise the corporate industrial food regime and force food producers (and consumers) into global markets at the expense of more localised food networks, cultures and rural livelihoods [17].

In this current effort to (re)define the meaning of organic agriculture, there is strong shift towards embracing the principles of agroecology. Although it is also not free from ambiguities and can have different meanings depending on the context, the term agroecology refers to a vision of the agri-food system and a set of practices encompassing a scientific approach, a bottom up movement, and an aim of transforming the industrial food system in order to achieve food sovereignty [18,19]. Agroecology is defined as a way of life based on ecological and social justice principles, and includes a defense of the collective rights to food and access to the commons (e.g., seeds, water, land, genetic resources). It also involves a recognition of an interconnected relationship between humans and the rest of nature, thus revaluing traditional, indigenous and peasant knowledge (as well as cosmovisions), and has an interest in the prioritisation of local food webs based on new social relations over globalised markets.

As this discussion highlights, organic agriculture has many faces. For some people it appears as the practices of traditional farming prior to industrialisation, including those of poor subsistence farmers today [20]. For others, it involves large-scale market oriented initiatives operated by certified practitioners [21]. For others still, it involves an agroecological movement drawing on both traditional practices and modern science to pursue not only an alternative agronomic but also a socio-political agenda for agri-food systems [22-24]. In this article, we see it as crucial that the definition of organic farming is neither limited to the traditional practices of poor farmers nor narrowed to only the non-chemical input approach of certification norms, but is recognised as a wide spectrum of practices and ideas. In our use of the umbrella term, organic agriculture entails a transformative vision, a vision that acknowledges and approaches agriculture as an interconnected socio-ecological system.

\subsection{Defining What Is GM}

The term organic agriculture contains a spectrum of different meanings and practices and this is also the case with GM. GM is usually used as an acronym for Genetic Modification, although it can also be taken to stand for Genetic Manipulation, as used in this special issue. GM can also be referred to as GE, Genetic Engineering, although language is significant here and the use of the term engineering can be critiqued for implying an inaccurate and misleading level of precision and control. Both GM and GE are, however, terms used to refer to techniques within the field of "modern biotechnology". The International Cartagena Protocol on Biosafety [25] defines modern biotechnology as: injection of nucleic acid into cells or organelles, or

(2) Fusion of cells beyond the taxonomic family, that overcome natural physiological reproductive or recombination barriers and that are not techniques used in traditional breeding and selection. 
The majority of GM crops in commercial use today are transgenic organisms created through the use of recombinant DNA (rDNA) technology. In this process, DNA from different species (indeed often different kingdoms) is manipulated and merged into a multi-component genetic cassette (typically including viral promoter and bacterial terminator sequences) that is then randomly inserted into the target organism's genome. This is done using either particle bombardment delivered through a gene gun or with the help of the bacterium Agrobacterium tumefaciens, a plant pathogen naturally able to transfer DNA into plant cells.

In contrast with the long history of promises regarding the potential of GM crops to overcome a multiplicity of agrarian and social problems, actually only two main types of GM crops developed using this technology dominate today's commercial market-those that are herbicide-tolerant and those that are pesticide-producing. In fact, herbicide-tolerant crops, in which the crop has been genetically modified in order to be able to survive the application of a deadly herbicide, constitute about $53 \%$ of GM agricultural applications, while $14 \%$ have been modified to produce a pesticide, and $33 \%$ now include both types of traits stacked together [26]. Although the use of rDNA technology to create transgenic crops expressing these traits has dominated to date, this has the potential to change rapidly as new techniques for genetic manipulation continue to emerge.

A range of new plant breeding techniques (NPBTs) are now available (see Figure 1), especially for what is being referred to as "genome editing". This includes the use of site directed nucleases (SDN) and oligonucleotide directed mutagenesis (ODM) $[27,28]$. Both of these types of techniques for genome editing create breaks in DNA and then employ the natural repair mechanisms of cells to integrate desired changes. SDNs use agrobacterium, particle bombardment, or agroinfiltration methods to insert enzyme complexes (such as zinc finger nucleases, TALENs, and the CRISPR-Cas system) into cells to target chosen sequences of DNA and make single or double stranded breaks, which when repaired by the cell can lead to the deletion, substitution or insertion of desired genetic sequences. ODM techniques in contrast, deliver oligonucleotides into cells (typically either by particle bombardment or electroporation) in which the introduced DNA is the same as the target organism's, except for a particular insertion, deletion or mismatch. The oligonucleotide then attaches to the targeted DNA sequence and triggers the repair mechanism of the cell to use the oligo insert as the correct template to rewrite the native genome.

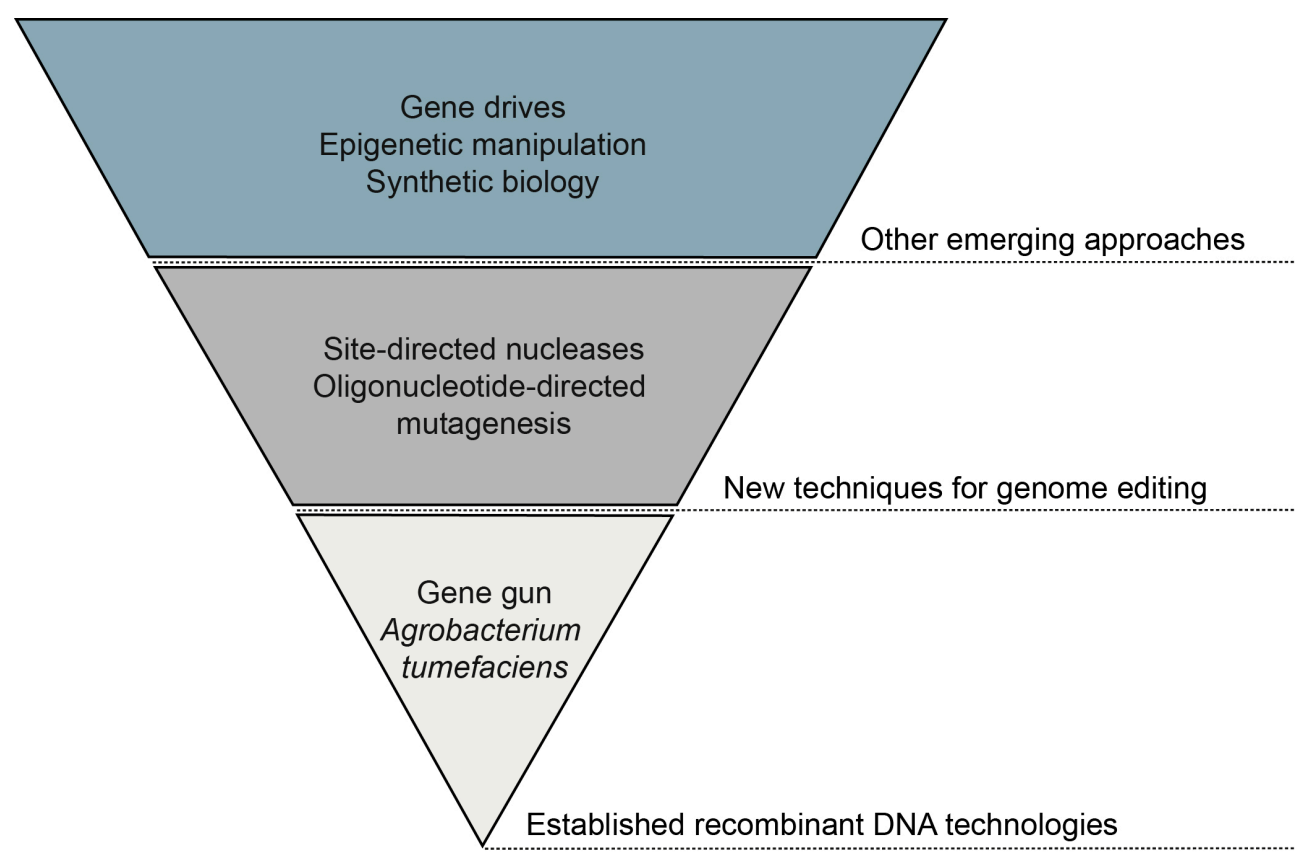

Figure 1. The development of tools for genetic modification. 
Both of these new techniques enable more directed and targeted alterations in the genome than has previously been possible with rDNA technology. However, unintended off-target effects resulting from the technology still require thorough investigation. This is necessary because despite the widespread assumption (and regular declaration) that these novel techniques are precise, little research has been done on their effects across the entire genome and the limited available information to date has already indicated the potential for off-target changes [29]. While some will dismiss the significance of such changes by highlighting that genetic mutations can also arise naturally, this does not mean that any potential off target effects from the use of genome editing techniques will necessarily be harmless. Experience teaches us that even small genetic changes can have large consequences. Our knowledge of how the genome functions is continually evolving and our experience with these new tools is simply too limited at this point to declare that potential off-target effects will not happen or will be irrelevant if they do. Unintended changes brought about by the use of these new techniques needs to be studied scientifically rather than simply assumed not to occur or to be harmless because mutation is a natural phenomenon. Context matters and it is, therefore, important to examine the significance of any off-target effects on a case by case basis. It is also crucial that researchers sequence the entire genome and perform omic forms of analysis (e.g., proteomics and transcriptomics) if we are to truly understand the operation and impact of these novel technologies in detail. Furthermore, to understand what impact the induced changes may have on the organisms involved or what risks such organisms may pose, we would also ideally study them over generations and across different environmental contexts.

Other relevant new techniques emerging within biotechnology that are worth noting here include the development of gene drives (approaches facilitating a biased inheritance of particular genes) [30,31] and epigenetic manipulation, in which gene regulation is altered through DNA methylation, or RNA interference where gene expression is silenced by destroying messenger RNA molecules [32-34]. Beyond the application of these new techniques in plant breeding, these tools are also now being used to manipulate other organisms in agricultural systems. For example, to modify agricultural insects and pests, particularly for the trait of sterility as an approach to population control [35]. While this approach is particularly being explored to control populations of wild organisms linked to human disease (e.g., mosquitos implicated in the spread of malaria), there is also research being conducted into their use to remove problematic pests or weeds in agricultural areas and particularly in combination with gene drives, which allow certain genes to be positively biased in sexually reproducing organisms so that they become dominant and spread to all members of a population [36]. There is also a significant level of investment into the development of synthetic biology [37], although commercial applications of this within agriculture may be further into the future than the other NPBTs described.

The emerging range of NPBTs provide enhanced scope for not only transgenic recombination of genetic code but also for cisgenic modification [38]. While transgenesis involves combining genetic sequences across different species (or kingdom) boundaries, cisgenic changes involve the use of genetic information from either the organism itself or from a sexually compatible donor. Cisgenic changes can also be brought about through conventional breeding, although the use of NPBTs is said to increase the speed and accuracy at which they can be produced and are more appealing for these reasons [38]. While the ability of NPBTs to make small or cisgenic changes is often emphasised in arguments for why these technologies should promote a reconsideration of the acceptability and regulatory requirements for GMOs, it is also important to note that the technology itself is not restricted to making these types of modifications and can also be employed to make large and transgenic types of changes within an organism's genome.

The rapid development and application of this range of new techniques for genetic manipulation in recent years has posed significant challenges for existing definitions of both biotechnology and genetically modified organisms in legal and regulatory contexts. This is because such definitions have often specifically referred to the use of particular technologies as the defining characteristic (as illustrated above) and/or because organisms manipulated using these techniques may contain no foreign DNA at the end of the process. Countries around the world are therefore now grappling with 
questions of how to understand the nature of these new techniques, as well as the ontological and legal status of the organisms generated through their use, and the extent to which research and development in these areas is covered by or exempt from existing regulatory systems $[39,40]$.

Given the explosive development of new GM approaches, possible applications and organisms in recent years, as well as the uncertainty surrounding their identity and status within existing classifications and regulatory systems, this special issue has raised the question of how they will be related to by the organic movement. Is there potential for the antagonistic relationship that currently exists between organic and GM forms of agriculture to change with the emergence of this wider spectrum of possibilities within the GM sphere?

\subsection{GM Use in Organics? The Framing Issue}

Most claims for the integration, uptake and acceptance of GM into organic agriculture are based on the assumptions that: (1) organic farming has unacceptably low yields; (2) that these techniques can improve the yields of organic farming; (3) these techniques are the best way to improve yields and; and (4) yields are the main aspect of interest [21,41-43]. These assumptions ignore the range of scientific evidence challenging the claims related to organic vs. conventional yields [44-46] and directly collide with the multidimensional values that shape and define organic farming $[47,48]$. In doing so, they crystallise an expression of the clash between the agroindustrial (including both GM and chemically-intensive farming) and agroecological cultures of agriculture [49-51]. This clash involves antagonistic worldviews, including different sets of beliefs, values, visions and norms shaping social and political action, and in this case, also agricultural practices [51,52]. These different worldviews also draw on different scientific paradigms [53], creating fundamental differences in the way problems are framed and understood, how knowledge is approached and generated, as well as the way solutions are imagined and enacted.

These fundamental differences become clear in disagreements about the compatibility of GM and organic farming, with proponents of different sides of the argument seeing and interpreting reality through different lenses, which affects the type of questions asked, the structure and nature of these questions, the types of solutions proposed, and ultimately, the position adopted on the issue. Amman [21], for instance, praises productivism and claims that GM could enhance organic farming yields. He strongly argues in favour of monocultures as the core agrarian practice in his "integrative" proposal and considers biodiversity as an aspect that has to be protected outside production fields. At the same time, his vision of agriculture is remarkably restricted to technical and managerial aspects, limiting the consideration of the wide spectrum of organic farming to only market-oriented large-scale certified production practices, with monocultures engaged in production for global markets being presented as the only viable way forward.

Contrastingly, organic farming proponents do not necessarily regard yield as the most fundamental aspect of farming that has to be maximised. Rather, they emphasise the importance of multifactorial social and ecological values, including supporting biodiversity, reducing energy use, boosting soil fertility, improving water quality, encouraging equality, enhancing autonomy, reducing worker exposure to pesticides etc. [47,48,54]. Indeed, in the productivist worldview, insect pests and weeds may be seen as key problems that have to be addressed to deliver higher yields and so solutions to reduce these are pursued through technological means-e.g., chemical sprays or GM plants. However, according to an agroecological worldview, large-scale monocultural cropping may be seen as the underlying problem that leads to out of control insect infestations and weed problems and intercropping, crop rotation, encouraging natural predators and some degree of acceptance may be pursued as the most appropriate solutions. According to this perspective, GM crops appear, at most, as a temporary fix that does not address the underlying cause of the problem and instead creates new problems of evolved resistances to the technological solutions and increasing dependencies on external inputs, actors, and knowledge [55,56]. 
The different worldviews of the agroindustrial and the agroecological models do not only seek to maximise different values and have divergent approaches to how problems are framed and solutions pursued, they also vary in their views on human-nature relations, the role of different types of knowledge in the agri-food system and the appropriate regimes of ownership and control. For example, within the agroecological model, open access to plant genetic resources is seen as a fundamental right, while GM models of agriculture have favoured private property regimes and aggressively pursued intellectual property rights in the form of monopoly patent protection of not only modification techniques, but also genes and organisms, which has allowed for extensive concentration in the GM seed market. This latter approach is in fundamental conflict with an agroecological worldview in which human beings are not seen as inventors of living organisms and systems but rather as caretakers, co-creators or custodians. From this perspective, it is key to recognise farmer's rights and the role of local and indigenous communities in the conservation and development of plant genetic resources, which constitute the basis of food and agricultural production.

Intellectual property regimes play a key role in turning GM processes and products into "commodities" that can be freely traded in a globalised and liberalised market [56,57]. Indeed the role that the market, free trade, and the economic growth agenda can play in the creation of social wealth and well being and the alleviation of poverty and hunger is central in the clash between the agroindustrial and the agroecological visions of the future of agri-food systems. While facilitating free trade in globalised markets aimed at maximising economic growth is a primary means for improving rural livelihoods for the proponents of industrial agriculture- that should perhaps be better tuned to integrate environmental goals - they are the drivers of inequality, ecological destruction and the deterioration of food sovereignty from the perspective of organic proponents.

What this framing discussion demonstrates is not simply that one of these models is scientific while the other merely ideological, as sometimes claimed by GM proponents $[21,58]$. Both approaches emphasise the importance of science, although they emphasise different fields as most relevant and useful, e.g., differentially weighing the potential contribution of molecular biology and genetics vs. ecology and the social sciences [59]. They also both express ideological commitments, although they differ in exactly which socio-political values are propounded as being of central importance, diverging across classic dualisms such as individualism/collectivism, technocracy/democracy, and productivism/environmentalism. Both worldviews therefore contain their own ideologies and science, with the agroindustrial model advocating a technoscientific intensification of agriculture while the agroecological model offers a transformational vision based on relational natural and social sciences and a different set of values than those currently predominating and prioritised in western industrialised nations.

The idea that GM and organic agricultures stem from different worldviews, ideologies, values and paradigms is not new. However, as several agri-food scholars have pointed out, in reality, these two worldviews operate as poles characterising the ends of a spectrum and there is significant scope for shades of grey in between $[16,60,61]$. This refers, especially, to the aforementioned processes of the conventionalization of organic agriculture in which certain norms of the organic vision are adhered to (e.g., no synthetic chemical inputs) concomitantly with operation under a largely industrial model (e.g., large-scale monocultural production for global markets). At the same time, there is an increasing level of emphasis being placed within conventional industrial farming, including GM, on the importance of organic values such as environmental sustainability, with emphasis now often placed on how GM can advance a sustainability agenda (e.g., in reducing chemical use or advancing no till farming).

To analyse the position of organic agriculture on GM and consider what potential there is for the new wave of NPBTs to be taken up by the organic movement, we will now analyse the 2016 revised draft position statement of IFOAM on GMOs [3] and the published position of IFOAM Europe on NPBTs [6]. In the following section we will describe the different arguments presented in these position statements and analyse the range of significant conditions that would need to be met if new GM technologies are to be given any place within organic agriculture. 


\subsection{The IFOAM Position Statements on GMOs}

In the draft revised IFOAM position statement on GMOs (developed as a consensus document through a participatory process engaging all organisations under the IFOAM umbrella and released for public consultation in March 2016), GE is defined in a broad way to include NPBTs and synthetic biology. In the first point following their definition of terms and outline of the scope of interest, the document emphasises that the current status is that the intended use of GMOs is excluded from organic systems, except for the unique exception of the use of GM vaccines in livestock when animal welfare is significantly threatened and other alternatives are not available. After these opening statements, the position paper is organised around the following subsections: GE must be developed and used responsibly; Deployment of GE must be based on clear evidence of its benefits; Ensure the common good: reform public policy and laws regarding genetic engineering the release and market presence of GMOs, and; Coordinate actions in the market. Our analysis presented below will follow the same structure (for a summary of the arguments see Figure 2).
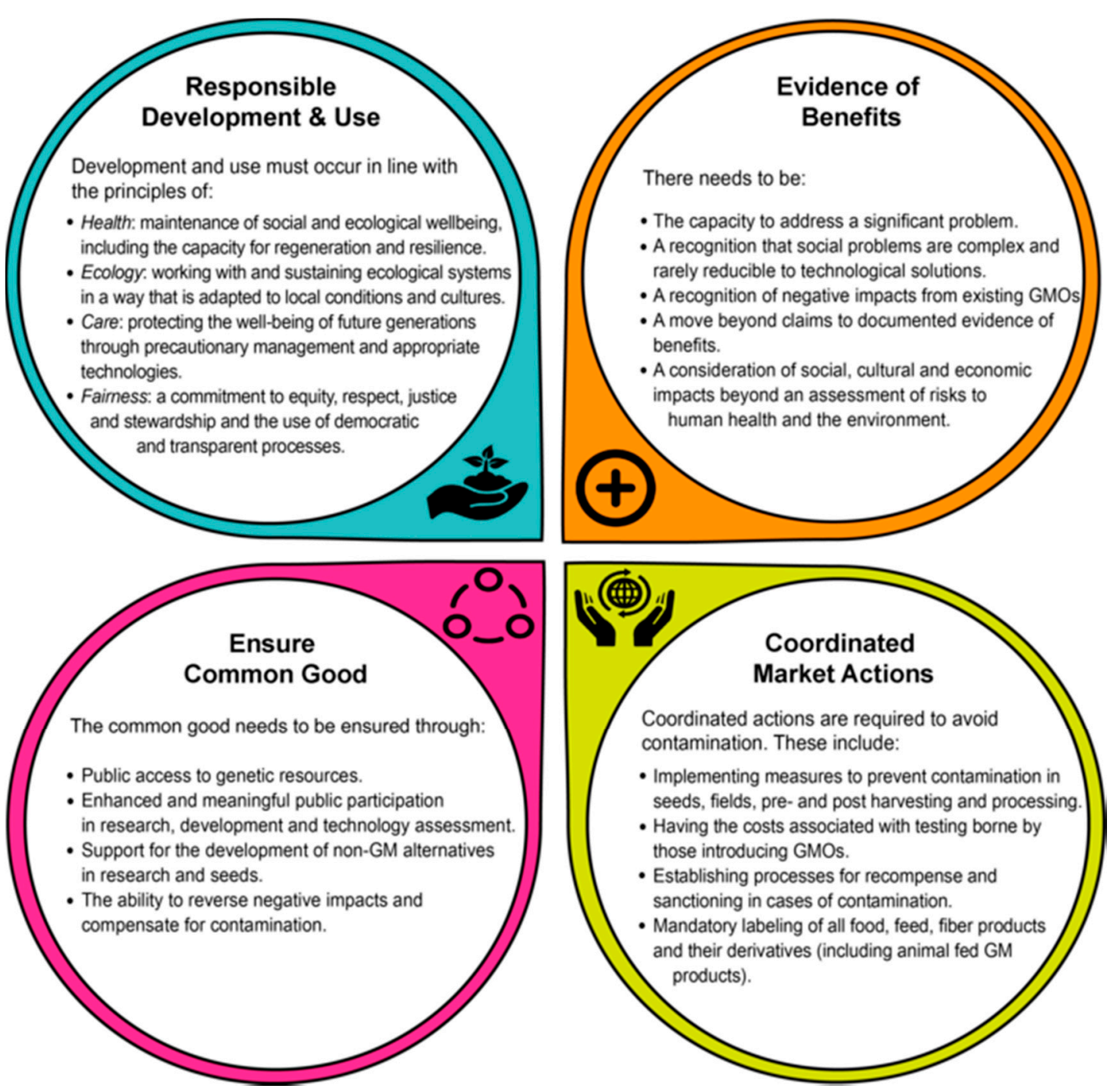

Figure 2. Summary of IFOAM requirements for GMOs.

As these organising criteria indicate, the IFOAM is not simply interested in the traits of particular GM plants and whether they may align with the oft perceived key feature of organic agriculture as a reduced use of synthetic inputs. Rather, IFOAM advances a much broader picture of what 
organic agriculture is committed to, which includes not only health and environmental goals but also particular social and political ideals—an alternative culture of agriculture. Adopting this position means that NPBTs would need to satisfy a range of diverse criteria to be acceptable and not simply reduce the use of toxic inputs in agricultural systems. This means that a GM plant that may reduce pesticide use would not necessarily be acceptable within the organic movement if, for example, the intellectual property rights applied to it failed to ensure the common good, if it wasn't developed through transparent participatory dialogue with stakeholders, or if there was no evidence for its claimed benefits being sustainable over the long term. The position against GMOs articulated by the organic movement represents a systems-based critique of industrial models of agricultural research, development, production and consumption, which is not necessarily overcome by changing one component of that system (e.g., creating a different type of GM crop). The broad range of demands NPBTs would have to meet to be acceptable within the organic movement and the nature of their systems view and critique will become clearer as we articulate, unpack and analyse the different points of their position statements on GMOs below.

\subsubsection{Develop and Use GMOs Responsibly}

Under the first point that GM must be developed and used responsibly, IFOAM [3] refers to the principles of organic agriculture as a basis for its position. These are ethical norms meant to inspire action and include the principles of care, ecology, health and fairness. The principle of health proposes that "organic agriculture should sustain and enhance the health of soil, plant, animal and planet as one and indivisible". Here health is defined as more than just the absence of illness to include the maintenance of social and ecological wellbeing, as well as characteristics of regeneration and resilience. The principle of ecology refers to the way in which "organic agriculture should be based on living ecological systems and cycles, work with them, emulate them and help sustain them". Here emphasis is placed on having production based on ecological processes in a way that is adapted to local conditions and cultures and in which inputs are reduced by reuse and recycling. Farming design is also required to work towards not just protecting but actively benefiting the environment (including climate, biodiversity, air and water quality). The principle of fairness refers to the way in which "organic agriculture should build on relationships that ensure fairness with regard to the common environment and life opportunities". Fairness here is characterised by equity, respect, justice and stewardship among people and in relation to other living beings. It also emphasises that environmental resources should be managed in a way that is socially and ecologically just and held in trust for future generations. The principle of care is described as the way in which "organic agriculture should be managed in a precautionary and responsible manner to protect the health and well-being of current and future generations and the environment". Here emphasis is placed on the way in which organic agriculture practitioners should carefully balance any enhancement of efficiency and productivity with potential impacts on health and well-being, with particular attention needing to be paid to exercising care in the long-term in the face of uncertainty. Suggesting that responsibility is key for technology choice in organic agriculture, the principle of care proposes that scientific knowledge can be usefully supplemented with practical experience, accumulated wisdom and traditional or indigenous knowledge. Furthermore, decisions should focus on appropriate rather than unpredictable technologies and reflect the values of those affected through transparent and participatory processes.

While the content of these principles is overlapping to some extent and (re)appears under other points of the position statement, in this first section it is stated that existing GMOs have violated the principles of health and ecology (e.g., through negative impacts on biodiversity and soil fertility) and also violated the principle of fairness through failing to contain the spread of GM contamination into organic fields. This section of the position statement also suggests that the principle of care should be the main guide for all research, experimentation and release of GMOs. As currently articulated, this principle of care places importance on the adoption of both long-term, intergenerational thinking and 
evaluation, as well as a precautionary stance towards new technologies so as to minimize exposure to negative impacts.

The principle of care used by IFOAM connects with feminist care ethics, which adopts a relational ontology and argues for the importance of paying attention to factors such as the distribution of power and vulnerability, as well as the specifics of context and narrative in any assessment of desirability [62]. Furthermore, the emphasis IFOAM places on responsible development links to the growing policy discourse of Responsible Research and Innovation (RRI). In RRI, scientific research, technological innovation and their governance are being required to address and orient around new norms $[63,64]$. These include: (1) A focus on addressing significant socio-ecological needs and challenges; (2) A commitment to actively engaging a range of stakeholders for the purpose of substantively better decision-making and mutual learning; (3) A dedicated attempt to anticipate potential problems, assess available alternatives and reflect on underlying values, assumptions and beliefs; and (4) A willingness among all participants to act and adapt according to these ideas [65]. This means that IFOAM's guiding principle of care and its notion of responsible development and use is usefully supported by work in other fields, such as science policy and philosophical ethics.

Questions of health and food safety have traditionally been given significant weight by both producers and consumers in their choice to go organic and it is important to emphasise that for IFOAM, the health principle also encompasses not only human but also animal, plant, soil and ecosystem health as well. Furthermore, the health principle of IFOAM specifically extends beyond the absence of illness to the enhancement of wellbeing and characteristics such as potential for regeneration and resilience. The impacts of GM crops on food safety and human and animal health have been the subject of extensive debate for decades and scientists have differentially interpreted the available evidence to claim both that there is a consensus that they are safe [66] and that a lack of such consensus exists [67]. Such disagreement persists due to the inherent flexibility in terms of how protection goals are framed, how research questions are formulated and what is deemed to be an appropriate method and timeframe for testing. One of the major conflicts around safety testing has, for example, been whether GMOs are best tested in isolation or in combination with the co-technologies (such as the chemical sprays) they are in practice grown together with. Significant questions have also been raised about the quality of the available evidence on questions of health and safety and the lack of transparency on both methods and results in such studies, particularly for the industry funded studies used in governmental evaluations [68,69]. Even if concerns around the quality and transparency of research on health risks from GM crops could be addressed, it is worth noting that current assessment regimes do not evaluate issues of well-being more broadly nor characteristics such as the potential for regeneration and resilience as highlighted as important for IFOAM.

Interestingly, IFOAM [3] concludes this section of its position with the statement that “Technologies such as GMOs should only be introduced-and then under controllable circumstances only-based on democratic, transparent assessment of the technology through processes that include decision-makers from every area of society and every group of people who will be impacted by the technology". What is interesting about this statement is that it does not appear to exclude GMOs and NPBTs in principle, but rather takes issue with the degree to which they can be contained and controlled and the extent to which their development has been transparent and their governance democratic. Given the history of how GMOs have been developed and governed this is a legitimate concern. There have been persistent calls for opening up the development and governance of agricultural biotechnology to more democratic processes and input (e.g., through broader public engagement and participation) [70-72] and indeed, the current emphasis on developing responsible forms of research and innovation largely stems from the perceived failings of how biotechnology has been handled in the past. If NPBTs become exempt from regulation, or are governed by existing flawed frameworks that have perpetuated social controversy by excluding social and ethical aspects [73,74], then it seems highly unlikely that new genetic technologies and applications will meet IFOAM's requirements for more transparent or democratic assessment. Furthermore, their novelty and lack of history of safe 
use entails a degree of unpredictability that does not sit well with the principle of care as articulated by IFOAM. Practical experience with the history of GM traits developed for commercial use also shows no attention given to long-term thinking. This is evidenced by the fact that the development of resistance amongst weeds and insects to the GM traits was predicted from the outset and has now lead to a technological treadmill in which traits are now being stacked together as a management strategy (with some GM crops now containing up to 8 different traits, including the production of 6 different pesticides and tolerance to two different herbicides [75,76]). Of course since the profitability generated by patent protection is only available for a period of 20 years, commercial businesses are also not always motivated to consider long-term solutions and may prefer to generate products with a kind of "planned obsolescence". This situation suggests that unless significant changes in governance are implemented to prohibit NPBTs from following the same trajectory as previous biotechnologies, they will fail to meet IFOAM's criteria for responsible use and development.

\subsubsection{Provide Evidence of Benefits}

Taking an in-context-trajectory perspective [77], the draft IFOAM position states that the future use of GM must be based on clear evidence of its benefits, and a thorough assessment of both its risks and capability to respond to certain needs (in a problem-solving perspective). The IFOAM position then reflects on the limited assessment of GMOs that is the current norm, which only takes environmental and health risks into account. To expand this, the position statement calls for the consideration of social, cultural and economic impacts in decision-making. It also calls for the consequent recognition of documented negative socio-environmental impacts, such as: a reduction in the diversity of available seeds [78-80]; the evolution of weeds resistant to the co-technology herbicides resulting in the use of additional and more toxic agrochemicals [81]; development of resistance to GM crops in insect pest populations [82,83]; increased pesticide residues in food [84]; or disruption of rural social structures and cultures [85], among others. The draft position paper attributes the reported problems both to the traits expressed by the GMOs themselves or the way in which their production and introduction occurs. On this point, the position could be expanded to critically question the sufficiency of health and environmental assessment related to co-technologies and production systems, as well as recognise that social, cultural and economic impacts can also be assessed scientifically.

There have been persistent promises from proponents on the capacity of GM products to solve complex problems (e.g., drought-tolerant crops adapted to changing climates [86] or cultivars with enhanced phytonutrients to alleviate diet-related diseases such as cancer, hypertension or diabetes [87]). Despite decades of research and development though, commercial GM crops have failed to deliver on such promises and remain dominated by herbicide-tolerant and pesticide-producing traits, with any innovation largely restricted to trait stacking. As already suggested, these traits have little to offer the agroecological approach. The consistent failure of GM to deliver on its promised broader benefits creates significant grounds for scepticism that this will change with NPBTs, despite the same promises reemerging and being perpetually repeated. Beyond the discussions on the technical capacity of GM to deliver such results $[88,89]$, from the agroecological perspective the proposal that a technoscientific fix is available is highly reductionist and fails to acknowledge the social complexity of problems such as long-term hunger or poverty and the political drivers that cause and reproduce inequality [90,91]. It also radically simplifies (or even omits) the complex agronomic, institutional and livelihood contexts of introduction [88,92]. It is also worth noting the evidential bias involved when concrete empirical evidence of harm is always needed to prohibit a GMO, while hypothetical rather than evidenced claims of benefits are often sufficient to attract research funding and encourage their approval.

Assessing even the narrow promises of improving rural livelihoods through an increase in yield from GM crops requires a detailed critical examination of the available evidence in terms of the current and historical context of the application, the specific crop and trait being investigated, and the features being compared. This is because the devil is often in the detail and there is a need for a more consistent effort to gather empirical evidence, especially within a long-time frame and multifactorial 
value perspective. For instance, after reviewing 47 peer-reviewed articles using economic methods to measure the farm-level impacts of Bt cotton in developing countries, Smale and colleagues concluded that "the institutional and political context, which is mutable and often ignored, shapes economic impacts, especially over the longer-term. Most often, the contextual factors that influence whether a new variety succeeds or fails are more critical than whether yield advantages can be demonstrated in on-farm trials" [93]. The timeframe used is particularly important since, as the development of glyphosate-resistant weeds has shown, initial positive indications from GM crops often cannot be sustained over the long term $[55,94]$. For example, in the case of glyphosate-tolerant soy and cotton, not only has the required glyphosate dose to control weeds increased over time $[95,96]$, but also resistance development has now forced farmers to employ a cocktail of other more toxic herbicides together with these increasing doses [81]. Unless NPBTs can offer empirical evidence of benefits sustainable over the long-term and move beyond the same type of hypothetical promises of technoscientific fixes for complex political and socio-ecological problems, which have been perpetuated for decades without delivery, then they will not be awarded a place in organic agriculture.

\subsubsection{Ensure the Common Good and Reform Public Policy and Laws}

Under the section on ensuring the common good and reforming public policy and laws, the IFOAM draft statement again makes a call for enhanced and more meaningful public participation on a range of themes. This includes ensuring public access to genetic resources, increasing efforts to develop sustainable alternatives to GMOs, and reversing the spread of existing bad practice and products. Under the point referring to public access to genetic resources, emphasis is placed on the rights of farmers to save and trade seeds and the organic rejection of the legitimacy of patents awarded to life forms or their components. On the point regarding increasing efforts to develop sustainable alternatives, attention is called to the imbalance in the allocation of public resources. This means the favouring of GM research and development at the expense of investment in heritage and organic seed production and breeding, including participatory plant breeding practices. In referring to the need to reverse the spread of bad practices and products, the statement highlights how the existing system of GM farming has reduced access to non-GM seeds and lead to contamination without recourse for compensation.

How intellectual property rights will be pursued and play out for NPBTs largely remains to be seen. In the case of the CRISPR-Cas9 system, competing patent claims have been filed and remain subject to ongoing assessment and debate [97]. Given the history of GM development, the vast majority of those developing GM applications using these techniques will not likely be willing to forego pursuing intellectual property rights over their "inventions". One challenge to this, however, may emerge in relation to how their regulatory status plays out. For example, the current European definition of a GMO emphasises the question of whether these organisms are attained through natural breeding or recombination [98]. If proponents successfully argue that organisms created using NPBTs should be exempt from regulation on the basis that the changes could have occurred through natural breeding as well, surely any claim to the organisms as patentable inventions could also then be challenged as illegitimate. This is because to attain a patent requires a demonstration of novelty that could be called into question if natural breeding or recombination could deliver the same result.

In requesting enhanced support for the production and multiplication of non-GM seeds, IFOAM could also extend their position and call for research on both traditional and new varieties adapted to specific contexts, especially in light of climate change. Additionally, agroecological research on heritage varieties should also be accompanied by traditional knowledge of their associated agrarian practices and uses. The balance of available public funding is, however, arguably unlikely to swing towards enhanced support for organic science, seeds and breeding given the current high level of enthusiasm for NPBTs. It seems far more credible that interest in this new wave of biotechnological techniques will further restrict interest in and funding available for the development of organic approaches. While it could be argued that funding is not a zero sum game, public money available for research and 
development is clearly limited and history has demonstrated that investment in the development of technologies able to generate profits through patents rather than knowledge able to provide open access public benefit has been preferred. Rather than challenging this trend, NPBTs are arguably set to intensify it and further reduce both the funding and willingness to support genuine alternatives. Furthermore, it is also worth noting that the technology stewardship agreements farmers are required to sign to use patented GM technology prohibits them from performing research on the crops (e.g., [99]) and claims to confidential business information have inhibited the ability of independent researchers to access test materials and perform safety testing able to adequately inform assessment processes [69]. To date, no alternative system to guarantee such access and provide sufficient dedicated funding for independent safety testing has been articulated or implemented for NPBTs and it is not clear what restrictions may be placed on farmers' ability to save or perform research on seeds produced using these technologies.

The ability to recall GM products and reverse harm is already extremely challenging for existing products and will arguably also only be amplified in difficulty if NPBTs become widespread. This is because for many of these techniques (and especially in the cases where no foreign DNA is introduced), it can be extremely difficult to identify where they have been used without extensive genome sequencing or expensive omic analysis. Unless new techniques for detection and monitoring, or a system of watermarking transformed organisms, can be developed alongside the NPBTs, it seems impossible that the ability to identify, recall or limit the spread of GMOs (into organic farms or wild ecosystems) will be improved through their use. On this basis, NPBTs seem far from meeting IFOAM's criteria for ensuring the common good.

If the NPBTs are limited to making cisgenic rather than transgenic changes (meaning that the modifications mirror what is possible with natural mutations or alleles), questions may be asked about whether concerns regarding contamination would still hold. Of course if the GM organisms are subject to patent protection, unintended spread will continue to persist as a relevant issue for producers, users and non-adopters. However, even if the organisms were not subject to patent monopoly ownership, if objections to the GMO extend beyond just the trait involved and the nature of the product to include other aspects such as the process of genetic modification itself, the industrial system such a process stems from and perpetuates, and/or the attitude towards nature motivating the genetic modification, then there may still be a legitimate desire to exclude these organisms from organic forms of production. That is, concerns regarding contamination of organic systems from the undesired and uncontrolled spread of GMOs may still persist even if the NPBTs are limited in their use to the development of knock-out or cisgenic GM crops. This is because what is being critiqued and resisted is not necessarily just the specific product but also the general process of technologically manipulating the genetic code of organisms and the agroindustrial system that advances this as a solution to complex socio-ecological problems.

\subsubsection{Coordinate Actions in the Market}

The last section of IFOAM's 2016 draft stresses the importance of recognising the myth of coexistence between GM and non-GM crops and taking steps to proactively build, strengthen and expand food webs that are not compromised by GM contamination. This would mean not only developing and investing in the production and multiplication of non-GM seeds (as described above), but also giving special attention to the development of preventive measures against GM contamination. Such measures would need to take account of the potential for GM contamination via pollen drift in the fields, through admixture during pre- or post-harvest handling, and the potential use of contaminated additives, agents and ingredients in food product processing. In addition, as GM technologies continue to develop, new challenges are said to arise for organic operators as they can inadvertently encounter GM in new forms, such as in cleaning systems and products, in microbial cultures, and in other industrial uses. IFOAM claims that according to the principle of freedom of consumer choice, labeling of GMOs should be mandatory, not only for all food, feed and fiber products and their derivatives 
but also for animal products produced using GM feed. It is worth noting that in those countries (and for those products) where labeling of GMOs is not currently required, the organic label effectively functions as a form of GMO-free labeling for consumers. Should the sector begin to accept the use of GMOs though, the organic label would no longer function in this way and organic producers would likely lose the market share they currently hold from those not wishing to support or consume GM products.

Due to both the right of consumers to make informed choices and the permanent existence of the possibility of GM contamination in contexts of simultaneous GM and non-GM crop production, tests to trace GM have become a necessity within the organic agri-food system. IFOAM claims that organic producers should not have to incur the costs necessary to prove that the materials they use have no GMOs or GM derivatives, since coexistence between GM and non-GM crops is a situation that has been imposed upon them. This is specifically relevant for seed producers, as seeds are the most fundamental and vulnerable entity of the food web. Therefore, IFOAM claims a zero tolerance policy for GMO presence in seeds. IFOAM argues that the costs of testing with the most sensitive technologies in different nodes of the food web should be implemented and paid for by those who release GMOs onto the market and who therefore have a responsibility to control them. At the same time, organic operators could also conduct precautionary testing. IFOAM also highlights that in countries where contamination cases have taken place, an action threshold could be set that necessitates an inquiry into the root causes of the contamination and investigates appropriate remediation actions. Following the "polluter pays" principle, sanctions against trespassers for cases of contamination of non-GM crops should be put in place, including economic restitutions to compensate for both associated market losses and the loss of organic certification.

Since the position statement talks to all agriculture and is not restricted to the organic sector specifically, a final aspect of the IFOAM draft refers to enhancing communication and the sharing of information among both IFOAM members and other stakeholders to combat the negative impacts of GM and advance alternatives. For example, establishing partnerships and alliances with organisations outside the organic movement to oppose the use and spread of GMOs, producing stakeholder-specific communications to different actors within the food web, or sharing best practices to avoid GM contamination. Such new alliance building is arguably already taking place as both conventional and organic farmers are coming together to discuss labeling around animal feed sources, and as new categories such as "maize for human consumption" are being enacted [100].

As some countries refuse to consider GM contamination as a significant problem, the idea that control and containment will be enhanced with NPBTs seems highly unlikely. Mechanisms for systemic vigilance and monitoring would need to be more thoroughly explored, developed and put into place. Furthermore, public reporting on GM contamination cases across countries (without compromising the situation of the contaminated farmers) could be improved. At the moment an on-line contamination register exists, maintained by Greenpeace and GeneWatch UK [101], although not all actors in the sector register their contamination cases there. This can give a misleading impression of the locations and scope of contamination events. Most countries also fail to offer any public register of where GM crops are being sown or recompense if contamination occurs. The existence of a public register with the location of both experimental and commercial fields is a prerequisite for adopting measures to avoid contamination, as well as to assign responsibilities for contamination as needed. Support for contaminated farmers also needs to be addressed, for example, via an insurance fund. Without the existence of such mechanisms for communication and support, the marketplace will simply not contain the necessary structures for organic farming to avoid negative impacts from undesired GM contamination, whether this be via the use of either old or new biotechnologies. Furthermore, unless NPBTs have ways to clearly communicate their presence and dedicated measures for control, containment and recompense in the face of contamination, the organic sector seems likely to maintain its opposition to their uptake, use and spread. 


\section{Conclusions}

Proponents of agricultural biotechnology are calling for a reconsideration of the organic opposition to GMOs in light of NPBTs. This is despite any demand or perceived need for this from the international federation of organic agriculture movements. In this paper, we have sketched the diversity that exists under both the terms organic and GM and shown how disagreements on this issue involve a clash of agri/cultures between agroindustrial and agroecological approaches. Pointing to the potential for grey areas between the poles of a spectrum of beliefs and practices, our analysis then went on to focus on the newly revised draft position statement on GMOs from the IFOAM. Through this analysis, we suggest that given the history of experience with existing GMOs, the in-context-trajectory of biotechnology development, the continued narrow framing of agricultural problems and the ongoing exclusion of important socio-economic, political and cultural dimensions, NPBTs are unlikely to gain favour within organic movements given the criteria that are articulated as important for them. If GM advocates would like to see their applications embraced by the organic community, more substantial efforts will have to be made not just in the narrow terms of what traits are developed and what technologies are used, but also in: (a) how agricultural problems are understood and solutions imagined; (b) how the issue of ownership is considered and applied; (c) how regulatory assessment is informed and performed; (d) how issues of containment and control are developed and enacted and (e) the extent to which alternatives are investigated and supported. Unless deep cultural change takes place within GM research, development, orientation, assessment, and deployment, NBPTs will fail to meet the criteria of importance for IFOAM in much the same way as existing biotechnologies today. Therefore, we conclude that on the basis of its expressed criteria of importance, the organic movement should maintain its opposition to GM despite the emergence of NPBTs because currently, these new techniques appear to be writing the same old story.

Acknowledgments: This work has been supported by the Research Council of Norway (Grant No. 231146).

Author Contributions: Fern Wickson, Rosa Binimelis and Amaranta Herrero all contributed equally to the work in this paper, including its conception, design, data analysis and writing.

Conflicts of Interest: The authors declare no conflict of interest. The founding sponsors had no role in the design of the study; in the collection, analyses, or interpretation of data; in the writing of the manuscript, and in the decision to publish the results.

\section{References}

1. International Federation of Organic Agriculture Movements (IFOAM). Principles of Organic Agriculture. Available online: http://www.ifoam.bio/en/organic-landmarks/principles-organic-agriculture (accessed on 30 June 2016).

2. International Federation of Organic Agriculture Movements (IFOAM). Position on Genetic Engineering and Genetically Modified Organisms. Available online: https://www.ifoam.bio/sites/default/files/page/files/ ifoam-ge-position.pdf (accessed on 8 July 2016).

3. International Federation of Organic Agriculture Movements (IFOAM). Position on Genetic Engineering and Genetically Modified Organisms-Draft for Public Consultation. Available online: http://www.ifoam.bio/en/news/2016/02/26/public-consultation-position-ifoam-organicsinternational-genetic-engineering-and (accessed on 30 June 2016).

4. Howard, A. The Soil and Health; Schoken Books: New York, NY, USA, 1972.

5. Ryffel, G.U. Orgenic plants: Gene-manipulated plants compatible with organic farming. Biotechnol. J. 2012, 7, 1328-1331. [CrossRef] [PubMed]

6. IFOAM Europe. New Plant Breeding Techniques: Position Paper. Available online: http://www.ifoam-eu. org/sites/default/files/ifoameu_policy_npbts_position_final_20151210.pdf (accessed on 30 June 2016).

7. European Commission. Regulation 834/2007 on Organic production and labelling of organic products and repealing regulation (EEC) No 2092/91. Off. J. Eur. Union 2007, 189, 28-37. 
8. International Federation of Organic Agriculture Movements (IFOAM). Definition of Organic Agriculture. Available online: http:/ / www.ifoam.bio/en/organic-landmarks/definition-organic-agriculture (accessed on 8 June 2016).

9. King, F.H. Farmers of Forty Centuries; Rodale Press: Emmaus, PA, USA, 1911.

10. Balfour, E.B. The Living Soil; Faber and Faber: London, UK, 1948.

11. Treadwell, D.; McKinney, D.; Creamer, N. From philosophy to science: A brief history of organic horticulture in the United States. HortScience 2003, 38, 1009-1014.

12. Heckman, J. A history of organic farming: Transitions from Sir Albert Howard's War in the soil to USDA National Organic Program. Renew. Agric. Food Syst. 2006, 21, 143-150. [CrossRef]

13. Lockeretz, W. Organic Farming: An International History; CABI: New York, NY, USA, 2007.

14. Guthman, J. Commodified meanings, meaningful commodities: Re-thinking production-consumption links through the organic system of provision. Sociol. Rural. 2002, 42, 295-311. [CrossRef]

15. Niggli, U. Organic 3.0. Principles of organic agriculture-vision for a best sustainable practice-standards for a best sustainable practice. In SOAAN Meeting; Organic Eprints: Nuremberg, Germany, 2015.

16. Guthman, J. The trouble with 'organic lite' in California: A rejoinder to the 'conventionalisation' debate. Sociol. Rural. 2004, 44, 301-316. [CrossRef]

17. McMichael, P. A food regime genealogy. J. Peasant Stud. 2009, 36, 139-169. [CrossRef]

18. Anderson, C.; Pimbert, M.; Kiss, C. Building, Defending and Stengthening Agroecology: A Global Struggle for Food Sovereignty. Available online: http:/ /www.agroecologynow.com/wp-content/uploads/2015/05/ Farming-Matters-Agroecology-EN.pdf (accessed on 8 June 2016).

19. International Forum for Agroecology. Declaration of the International Forum for Agroecology. Available online: http:/ /agroecology.co.uk/wp-content/uploads/2015/03/Declaration-of-the-International-Forumfor-Agroecology.pdf (accessed on 8 June 2016).

20. Modi, A.T. What do subsistence farmers know about indigenous crops and organic farming? Preliminary experience in Kwazulu-Natal. Dev. S. Afr. 2003, 20, 675-684. [CrossRef]

21. Ammann, K. Integrated farming: Why organic farmers should use transgenic crops. New Biotechnol. 2008, 25, 101-107. [CrossRef] [PubMed]

22. Holt-Giménez, E.; Altieri, M. Agroecology, food sovereignty, and the new green revolution. Agroecol. Sustain. Food Syst. 2013, 37, 90-102.

23. Woodgate, G.; Sevilla Guzman, E. Agroecología: Fundamentos del pensamiento social agrario y teoría sociológica $=$ Agroecology: Foundations in agrarian social thought and sociological theory. Agroecología 2013, 8, 27-34.

24. Gliessman, S. Agroecology: Growing the roots of resistance. Agroecol. Sustain. Food Syst. 2013, 37, $19-31$.

25. CBD. Convention on Biological Diversity. Available online: https://www.cbd.int (accessed on 27 October 2016).

26. International Service for the Acquisition of Agri-Biotech Applications. 2015. Available online: http://www. isaaa.org/resources/publications/briefs/51/executivesummary/default.asp (accessed on 8 June 2016).

27. Agapito-Tenfen, S.; Wikmark, O. Current Status of Emerging Technologies for Plant Breeding: Biosafety and Knowledge Gaps of Site Directed Nucleases and Oligonucleotide-Directed Mutagenesis; GenØk Centre for Biosafety: Tromsø, Norway, 2015.

28. Hartung, F.; Schiemann, J. Precise plant breeding using new genome editing techniques: Opportunities, safety and regulation in the EU. Plant J. 2014, 78, 742-752. [CrossRef] [PubMed]

29. Schiml, S.; Puchta, H. Revolutionizing plant biology: Multiple ways of genome engineering by CRISPR/Cas. Plant Methods 2016, 12, 1-9. [CrossRef] [PubMed]

30. Esvelt, K.M.; Smidler, A.L.; Catteruccia, F.; Church, G.M. Concerning RNA-guided gene drives for the alteration of wild populations. eLife 2014, 3, e03401. [CrossRef] [PubMed]

31. Oye, K.A.; Esvelt, K.; Appleton, E.; Catteruccia, F.; Church, G.; Kuiken, T.; Lightfoot, S.B.-Y.; McNamara, J.; Smidler, A.; Collins, J.P. Regulating gene drives. Science 2014, 345, 626-628. [CrossRef] [PubMed]

32. Heinemann, J.A.; Agapito-Tenfen, S.Z.; Carman, J.A. A comparative evaluation of the regulation of GM crops or products containing dsRNA and suggested improvements to risk assessments. Environ. Int. 2013, 55, 43-55. [CrossRef] [PubMed]

33. Ali, N.; Datta, S.K.; Datta, K. Rna interference in designing transgenic crops. GM Crops 2010, 1, $207-213$. [CrossRef] [PubMed] 
34. Lusser, M.; Parisi, C.; Plan, D.; Rodríguez-Cerezo, E. Deployment of new biotechnologies in plant breeding. Nat. Biotechnol. 2012, 30, 231-239. [CrossRef] [PubMed]

35. Waltz, E. Oxitec trials GM sterile moth to combat agricultural infestations (vol 33, pg 792, 2015). Nat. Biotechnol. 2015, 33, 896. [CrossRef] [PubMed]

36. Ledford, H. Crispr, the disruptor. Nature 2015, 522, 20-24. [CrossRef] [PubMed]

37. Church, G.; Regis, E. Regenesis: How Synthetic Biology Will Reinvent Nature and Ourselves; Basic Books: New York, NY, USA, 2012.

38. Schaart, J.G.; van de Wiel, C.C.M.; Lotz, L.A.P.; Smulders, M.J.M. Opportunities for products of new plant breeding techniques. Trends Plant Sci. 2016, 21, 438-449. [CrossRef] [PubMed]

39. Lusser, M.; Davies, H.V. Comparative regulatory approaches for groups of new plant breeding techniques. New Biotechnol. 2013, 30, 437-446. [CrossRef] [PubMed]

40. Kuzma, J.; Kokotovich, A. Renegotiating GM crop regulation: Targeted gene-modification technology raises new issues for the oversight of genetically modified crops. EMBO Rep. 2011, 12, 883-888. [CrossRef] [PubMed]

41. Ronald, P. Plant genetics, sustainable agriculture and global food security. Genetics 2011, 188, 11-20. [CrossRef] [PubMed]

42. Azadi, H.; Ho, P. Genetically modified and organic crops in developing countries: A review of options for food security. Biotechnol. Adv. 2010, 28, 160-168. [CrossRef] [PubMed]

43. Andersen, M.M.; Landes, X.; Xiang, W.; Anyshchenko, A.; Falhof, J.; Østerberg, J.T.; Olsen, L.I.; Edenbrandt, A.K.; Vedel, S.E.; Thorsen, B.J. Feasibility of new breeding techniques for organic farming. Trends Plant Sci. 2015, 20, 426-434. [CrossRef] [PubMed]

44. Badgley, C.; Moghtader, J.; Quintero, E.; Zakem, E.; Chappell, M.; Aviles-Vazquez, K.; Samulon, A.; Perfecto, I. Organic agriculture and the global food supply. Renew. Agric. Food Syst. 2007, 22, 86-108. [CrossRef]

45. Ponisio, L.C.; M'Gonigle, L.K.; Mace, K.C.; Palomino, J.; de Valpine, P.; Kremen, C. Diversification Practices reduce organic to conventional yield gap. Proc. Biol. Soc. 2015, 282. [CrossRef]

46. Seufert, V.; Ramankutty, N.; Foley, J.A. Comparing the yields of organic and conventional agriculture. Nature 2012, 485, 229-232. [CrossRef] [PubMed]

47. Altieri, M. The myth of coexistence: Why transgenic crops are not compatible with agroecologically based systems of production. Bull. Sci. Technol. Soc. 2005, 25, 361-371. [CrossRef]

48. Reganold, J.P.; Wachter, J.M. Organic agriculture in the twenty-first century. Nat. Plants 2016, 2, 1-8. [CrossRef] [PubMed]

49. Lang, T.; Heasman, M. Food Wars: The Global Battle for Mouths, Minds and Markets; Earthscan: London, UK, 2004.

50. Vanloqueren, G.; Baret, P.V. How agricultural research systems shape a technological regime that develops genetic engineering but locks out agroecological innovations. Res. Policy 2009, 38, 971-983. [CrossRef]

51. Levidow, L. European transitions towards a corporate-environmental food regime: Agroecological incorporation or contestation? J. Rural Stud. 2015, 40, 76-89. [CrossRef]

52. Beus, C.E.; Dunlap, R.E. Measuring adherence to alternative vs. conventional agricultural paradigms: A proposed scale. Rural Sociol. 1991, 56, 432-460. [CrossRef]

53. Kuhn, T.S. The Structure of Scientific Revolutions; The University of Chicago Press: Chicago, IL, USA, 1962.

54. International Federation of Organic Agriculture Movements (IFOAM). Best Practice Guideline for Agriculture and Value Chains. Available online: http://www.ifoam.bio/sites/default/files/best_practice_guideline_v1. 0_ratified_withcover.pdf (accessed on 7 June 2016).

55. Ceccarelli, S. GM crops, organic agriculture and breeding for sustainability. Sustainability 2014, 6, 4273-4286. [CrossRef]

56. McAfee, K. Beyond techno-science: Transgenic maize in the fight over mexico's future. Geoforum 2008, 39, 148-160. [CrossRef]

57. McAfee, K. Neoliberalism on the molecular scale. Economic and genetic reductionism in biotechnology battles. Geoforum 2003, 34, 203-219. [CrossRef]

58. Support Precision Agriculture. Laureates Letter Supporting Precision Agriculture (GMOs). Available online: http:/ / supportprecisionagriculture.org/nobel-laureate-gmo-letter_rjr.html (accessed on 8 June 2016).

59. Rivera-Ferre, M.G. Framing of agri-food research affects the analysis of food security: The critical role of the social sciences. Int. J. Sociol. Agric. Food 2012, 19, 162-175. 
60. Murdoch, J.; Miele, M. 'Back to nature': Changing 'worlds of production'in the food sector. Sociol. Rural. 1999, 39, 465-483. [CrossRef]

61. Sonnino, R.; Marsden, T. Beyond the divide: Rethinking relationships between alternative and conventional food networks in Europe. J. Econ. Geogr. 2006, 6, 181-199. [CrossRef]

62. Preston, C.J.; Wickson, F. Broadening the lens for the governance of emerging technologies: Care ethics and agricultural biotechnology. Technol. Soc. 2016, 45, 48-57. [CrossRef]

63. Stilgoe, J.; Owen, R.; Macnaghten, P. Developing a framework for responsible innovation. Res. Policy 2013, 42, 1568-1580. [CrossRef]

64. Hartley, S.; Gillund, F.; van Hove, L.; Wickson, F. Essential features of responsible governance of agricultural biotechnology. PLoS Biol. 2016, 14, e1002453. [CrossRef] [PubMed]

65. Wickson, F.; Carew, A.L. Quality criteria and indicators for responsible research and innovation: Learning from transdisciplinarity. J. Responsib. Innov. 2014, 1, 254-273. [CrossRef]

66. National Academies of Sciences, Engineering, and Medicine. Genetically Engineered Crops: Experiences and Prospects; National Academies of Sciences: Washington, DC, USA, 2014.

67. Hilbeck, A.; Binimelis, R.; Defarge, N.; Steinbrecher, R.; Székács, A.; Wickson, F.; Antoniou, M.; Bereano, P.L.; Clark, E.A.; Hansen, M. No scientific consensus on GMO safety. Environ. Sci. Eur. 2015, 27. [CrossRef]

68. Druker, S.M. Altered Genes, Twisted truth: How the Venture to Genetically Engineer our Food has Subverted Science, Corrupted Government and Systematically Decieved the Public; Clear River Press: Salt Lake City, UT, USA, 2015.

69. Nielsen, K.M. Biosafety data as confidential business information. PLoS Biol. 2013, 11, e1001499. [CrossRef] [PubMed]

70. Stirling, A. Opening up the politics of knowledge and power in bioscience. PLoS Biol. 2012, 10, 1-5. [CrossRef] [PubMed]

71. Horlick-Jones, T.; Walls, J.; Rowe, G.; Pidgeon, N.; Poortinga, W.; Murdock, G.; O'Riordan, T. The GM Debate: Risk, Politics and Public Engagement; Routledge: London, UK, 2007.

72. Levidow, L. European public participation as risk governance: Enhancing democratic accountability for agbiotech policy? East Asian Sci. Technol. Soc. 2007, 1, 19-51. [CrossRef]

73. Wickson, F.; Wynne, B. The anglerfish deception. EMBO Rep. 2012, 13, 100-105. [CrossRef] [PubMed]

74. Wickson, F.; Wynne, B. Ethics of science for policy in the environmental governance of biotechnology: MON810 maize in Europe. Ethics Policy Environ. 2012, 15, 321-340. [CrossRef]

75. Marra, M.C.; Piggott, N.E.; Goodwin, B.K. The anticipated value of smartstax ${ }^{\mathrm{TM}}$ for US corn growers. AgBioForum 2010, 13, 1-12.

76. Head, G.; Carroll, M.; Clark, T.; Galvan, T.; Huckaba, R.M.; Price, P.; Samuel, L.; Storer, N.P. Efficacy of smartsta ${ }^{\circledR}$ insect-protected corn hybrids against corn rootworm: The value of pyramiding the Cry3Bb1 and Cry34/35Ab1 proteins. Crop Prot. 2014, 57, 38-47. [CrossRef]

77. Pavone, V.; Goven, J.; Guarino, R. From risk assessment to in-context trajectory evaluation-GMOs and their social implications. Environ. Sci. Eur. 2011, 23. [CrossRef]

78. Roseboro, K. Finding Non-GMO Soybean Seed Becoming More Difficult: Fewer Breeding Programs for Non-Gmo Soybeans Are Reducing Supplies Despite Strong Demand. The Organic and Non-GMO Report. 2008. Available online: http://www.non-gmoreport.com/articles/jul08/non-gmo_soybean_seed.php (accessed on 8 June 2016).

79. Stone, G. Field versus farm in warangal: Bt cotton, higher yields, and larger questions. World Dev. 2011, 39, 387-398. [CrossRef]

80. Hilbeck, A.; Lebrecht, T.; Vogel, R.; Heinemann, J.A.; Binimelis, R. Farmer's choice of seeds in four EU countries under different levels of GM crop adoption. Environ. Sci.Eur. 2013, 25. [CrossRef]

81. Binimelis, R.; Pengue, W.; Monterroso, I. "Transgenic treadmill”: Responses to the emergence and spread of glyphosate-resistant johnsongrass in argentina. Geoforum 2009, 40, 623-633. [CrossRef]

82. Van Rensburg, J. First report of field resistance by the stem borer, Busseola fusca (fuller) to Bt-transgenic maize. S. Afr. J. Plant Soil 2007, 24, 147-151. [CrossRef]

83. Gassmann, A.J.; Petzold-Maxwell, J.L.; Keweshan, R.S.; Dunbar, M.W. Field-evolved resistance to Bt maize by western corn rootworm. PLoS ONE 2011, 6, e22629. [CrossRef] [PubMed]

84. Bøhn, T.; Cuhra, M.; Traavik, T.; Sanden, M.; Fagan, J.; Primicerio, R. Compositional differences in soybeans on the market: Glyphosate accumulates in roundup ready GM soybeans. Food Chem. 2014, 153, 207-215. [CrossRef] [PubMed] 
85. Stone, G.D. Biotechnology and the political ecology of information in India. Hum. Organ. 2004, 63, 127-140. [CrossRef]

86. Fedoroff, N.V.; Battisti, D.S.; Beachy, R.N.; Cooper, P.J.M.; Fischhoff, D.A.; Hodges, C.N.; Knauf, V.C.; Lobell, D.; Mazur, B.J.; Molden, D.; et al. Radically rethinking agriculture for the 21st century. Science 2010, 327, 833-834. [CrossRef] [PubMed]

87. Mattoo, A.K.; Shukla, V.; Fatima, T.; Handa, A.K.; Yachha, S.K. Genetic engineering to enhance crop-based phytonutrients (nutraceuticals) to alleviate diet-related diseases. In Bio-Farms for Nutraceuticals; Springer: Berlin, Germany, 2010; pp. 122-143.

88. Glover, D. Undying Promise: Agricultural Biotechnology's Pro-Poor Narrative, Ten Years on; STEPS Centre: Brighton, UK, 2009.

89. Varshney, R.K.; Bansal, K.C.; Aggarwal, P.K.; Datta, S.K.; Craufurd, P.Q. Agricultural biotechnology for crop improvement in a variable climate: Hope or hype? Trends Plant Sci. 2011, 16, 363-371. [CrossRef] [PubMed]

90. Nicholson, S. Genetically modified organisms and global hunger: A real solution? Sustain. Dev. Law Policy 2008, 9, 57-61.

91. Jansen, K.; Gupta, A. Anticipating the future: 'Biotechnology for the poor' as unrealized promise? Futures 2009, 41, 436-445. [CrossRef]

92. Fischer, K. Why new crop technology is not scale-neutral-A critique of the expectations for a crop-based african green revolution. Res. Policy 2016, 45, 1185-1194. [CrossRef]

93. Smale, M.; Zambrano, P.; Cartel, M. Bales and balance: A review of the methods used to assess the economic impact of Bt cotton on farmers in developing economies. AgBioForum 2006, 9, 195-212.

94. Shaner, D.L. The impact of glyphosate-tolerant crops on the use of other herbicides and on resistance management. Pest Manag. Sci. 2000, 56, 320-326. [CrossRef]

95. Bonny, S. Herbicide-tolerant transgenic soybean over 15 years of cultivation: Pesticide use, weed resistance, and some economic issues. The case of the USA. Sustainability 2011, 3, 1302-1322. [CrossRef]

96. National Research Council. Impact of Genetically-Engineered Crops on Farm Sustainability in the United States; The National Academies Press: Washington, DC, USA, 2010.

97. Ledford, H. Bitter fight over crispr patent heats up. Nature 2016, 529, 265. [CrossRef] [PubMed]

98. European Parliament. Directive 2001/18/EC of the European Parliament and of the Council of 12 March 2001 on the Deliberate Release into the Environment of Genetically Modified Organisms and Repealing Council Directive 90/220/EEC. 2001. Available online: http:/ / faolex.fao.org/docs/pdf/eur34933.pdf (accessed on 27 October 2016).

99. Monsanto. 2016 Technology Use Guide. Available online: http://www.monsanto.com/products/ documents/2016_tug_final.pdf (accessed on 5 October 2016).

100. Herrero, A.; Binimelis, R.; Wickson, F. Just existing is resisting: The everyday struggle against the expansion of GM crops in Spain. Forthcoming.

101. Greenpeace; GeneWatch UK. GM Contamination Register. Available online: http://www. gmcontaminationregister.org (accessed on 8 June 2016).

(C) 2016 by the authors; licensee MDPI, Basel, Switzerland. This article is an open access article distributed under the terms and conditions of the Creative Commons Attribution (CC-BY) license (http://creativecommons.org/licenses/by/4.0/). 